\title{
An Investigation of digital scholarship and disciplinary culture in Oman
}

\begin{abstract}
Purpose - The purpose of this study is to investigate disciplinary differences in the use of networked information for research and scholarly communication at Sultan Qaboos University, Oman. The study produced quantitative data on how and why academics within different disciplines utilise networked information either made available internally through the university library, or externally through services accessed by the Internet.

Design/methodology/approach - A questionnaire survey was conducted with academic staff at Sultan Qaboos University.

Findings-Statistical analysis found a number of significant differences between respondents in the science disciplines and those in the social sciences and humanities with regard to their use of, and attitudes towards, digital information services. While respondents from science disciplines show overall longer and more frequent use of networked information, respondents from humanities and social sciences indicated more positive attitudes toward library networked services.

Research limitations/implications - The Arab country context presents a challenge in determining the degree to which results can be extrapolated to other environments, in that disciplines are also divided by language. Science disciplines teach in English, and the social science and humanities in Arabic.

Originality/value - While similar studies have been undertaken in developed countries, this study is an attempt to establish some data for a developing Arab country.
\end{abstract}

Keywords - Academic libraries, Networking, Oman, Disciplinary culture, Scholarly communication, Languages.

Paper type - Research paper

\section{Introduction}

Networked information and communication and the Internet have fundamentally changed the manner in which scholars correspond and work. In particular these networking technologies have had a far-reaching impact on many aspects of the research environment, including collaborative research, the dissemination of research outputs, and the formation of scholarly communities.

As early as 1994, Bailey reported that "global computer networks, such as the Internet, have created a complex electronic communication system that has significantly changed the way scholars informally exchange information and has started to change formal scholarly publication activities” (p.7). By the late 1990s, these transforming effects of the Internet were being widely felt on the established (formal) systems of research and scholarly communication. Globally, academics and researchers were finding they could acquire information, undertake collaborative research projects, and communicate their research findings, far more easily and rapidly with the aid of networking technologies.

While the benefits of networked communication and content have been experienced by scholars and academic libraries globally, they have not been equally 
distributed. Universities and libraries in developing countries have struggled with various forms of technical and socio-cultural disadvantage in their attempts to optimise the benefits of digital scholarship. And while the impact of networked communication and information services have been frequently studied in the context of developed countries, much less research is available from developing countries, including the developing Arab countries. In particular, there have been no significant attempts to examine Arab scholars' attitudes to the networked environment based on their disciplinary affiliations. Studies of the adoption of the Internet and networked information by research communities therefore need to be conducted in developing Arab countries in order to;

- $\quad$ assess the information and technology gaps that exist between developing Arab countries and developed countries and also between developing Arab countries and other groups of developing countries,

- $\quad$ identify if patterns of research related uses of networking technologies in developing Arab countries have been influenced by local factors, such as the social, educational, and linguistic conditions,

- $\quad$ assess the impact that networking technologies have had on the research productivity of academics in developing Arab countries.

The research reported in this paper is derived from a survey undertaken at Sultan Qaboos University (SQU) in Oman. SQU was opened in 1986 as the first public university in Oman. At the time of the study the University consisted of seven colleges: Agriculture and Marine Sciences; Arts and Social Sciences; Commerce and Economics; Education and Islamic Sciences; Engineering; Medicine, and Sciences. A College of Law has since been added. At the time of data collection there were approximately 13,000 students enrolled at SQU, with over fifty Bachelor's degrees and thirty Master's degrees on offer.

The University provides various educational support centres to assist student learning, such as the Educational Technology Centre, Language Centre, and the Data System Centre. The University also supports a number of research centres, including those dedicated to water, the environment, oil, telecommunications, remote sensing, seismology, and Omani studies.

The Internet was made available to SQU in late 1997. Since that time the use of networked information and related technologies has become an essential asset in enhancing the University's teaching and research outcomes. Although the Internet and networked information are assumed to be widely used for research related purposes at SQU, there remains a need to investigate the precise extent and patterns of their use by academics for research and scholarly communication, and how this might in turn impact upon the research effectiveness of the University and the nation.

\section{Goal and objectives}

The goal of this research is to investigate whether there are disciplinary differences in the way in which networked information and communication are being used in an Arab academic environment.

The primary objectives of this study are to:

1. Investigate the use of networked information and its impact on patterns of research and scholarly communication in a developing Arab country, using 
SQU as an example.

2. Identify the disciplinary differences reflected in the use of networked information for research and scholarly communication.

\section{Review of the Literature}

The information use and scholarly communication patterns of researchers in all major academic disciplines have been studied for some time. It has been argued that scholarly communication is a social activity wherein relationships are influenced by the disciplinary culture within which scholars are grouped. Use of information by academics in science disciplines in particular has been examined closely. Some notable earlier studies include Menzel (1966) and Garvey, Tomita and Woolf (1974). Research into information use and scholarly communication in humanities and social science disciplines also increased during the 1960s and 70s. Examples of these studies include Simonton (1960) and Gleaves (1961) in the humanities, and Line (1971) and Skelton (1973) in the social sciences.

It should be noted that the literature of scholarship provides no absolute consensus as to what constitutes the "sciences", "social sciences" and "humanities". The sciences are frequently grouped into the natural sciences, physical sciences, and applied sciences, but each of these groups has been differently constituted at different points in time. Meadows (1998) states that at the beginning of the twentieth century "science" referred to natural sciences in English-speaking countries. He adds that lack of a universal definition of science leads to differences in organisational structures that in turn have an effect on communication patterns. For the purpose of this study, science is defined by the organisational structure of SQU where the science disciplines are divided into Colleges of Science, Engineering, Medicine, and Agriculture.

As with science, there is no universally accepted definition for the social sciences and humanities. Cohen (1993) indicates that social sciences are comprised by a set of disciplines that study social phenomena and relationships among people. It generally includes archaeology, economics, history, politics, psychology, and sociology. For some commentators, history is considered part of the humanities (Cohen, 1993). Humanities is said to refer to classical studies (Meadows, 1998), and White (1997) notes that "disciplines of the humanities such as philosophy, history, and literary studies offer models and methods for addressing dilemmas and acknowledging ambiguity and paradox. They can help us face the tension between the concerns of individuals and those of groups and promote civil and informed discussion of conflicts, placing current issues in historical perspective” (p. 263). In this study, social sciences and humanities are also based on the organisational structure of SQU. These include all departments affiliated with the Colleges of Arts and Social Sciences, Commerce and Economics, and Education and Islamic Studies.

Research investigating the scholarly use of networked communication and information in academic environments has included investigations of a single discipline; studies that are inter-disciplinary; and studies that are multi-disciplinary or cross-disciplinary. Studies that investigate a single discipline include Bishop (1994); Brown (2001); Shaw (1998); and Zhang (1999). Inter-disciplinary studies investigating use by academics in two or more academic disciplines within a broad area such as the social sciences include, Abels, Liebscher and Denman (1996; 1997); Costa and Meadows (2000); Eisend (2002); Seyal, Abd-Rahman and MahbuburRahim (2002). In an inter-disciplinary study conducted in a developing Arab country, Abdulaziz (2005) distributed a questionnaire to social science academics at Cairo 
University and Ain Shams University (also in Cairo). The findings indicated the comparatively slow take-up of the Internet by respondents, with $60 \%$ using the Internet less than 10 times per month. The majority of respondents (75\%) reported being unsatisfied with the capacity of the Internet to meet their information needs, with almost 60\% indicating that they cannot find relevant information in the Arabic language. Lack of skill and lack of English language proficiency were the most commonly reported barriers that prevented respondents from using the Internet effectively. It is certain, however, that Internet usage has increased in developing Arab countries, with a multi-disciplinary study undertaken at Kuwait University (AlAnsari, 2006) reporting Internet use by $89 \%$ of respondents.

Multi-disciplinary studies are those investigating and comparing the use of networked information by scholars in two or more broad disciplines, such as the social sciences disciplines compared to the sciences or humanities. Examples of multi-disciplinary studies conducted in developed countries include Applebee et al (1998); Applebee, Clayton and Pascoe (1997); Bane and Milheim (1995); Budd and Connaway (1997); Heterick (2002); Houghton, Steele, and Henty (2003); Kaminer (1997); Lazinger, Bar-Ilan, and Peritz (1997); Schauder (1994); and Wang and Cohen (2000).

Multi-disciplinary studies have also been conducted in developing Arab countries and almost universally indicated the comparatively slow uptake of the use of networked communication. In the United Arab Emirates, Boumarafi (2001) investigated the use of the Internet by academics at Al-Sharjah University, with the findings indicating a relatively low use of the Internet. The study found that lack of time, lack of training, and lack of English language proficiency were the major barriers to use, and recommended the need for training to improve Internet usage at the University. In an Algerian study, Bin-Alsabti (2003) surveyed 160 of 1773 academics at Mentouri University of Constantine, investigating use of networked communication. The results indicate that respondents preferred traditional methods of communication over electronic methods. The impact of networked communication was being felt, however, with almost $60 \%$ reporting some level of usage. When respondents were asked about the reasons for the use of networked communication, the majority (53\%) indicated exchange of information, ahead of research uses such as updating knowledge (22\%). While 40\% considered electronic information to be more important than print or traditional information, respondents indicated that technical problems were the most discouraging factor (42\%). For further examples of multi-disciplinary studies conducted in Arab and developing countries see Abdullah (1999); Adika (2003); Ehikhamenor (2003); Jirjees and Nashir (1999); Mamtora (2004); and Uddin (2003).

Garvey (1979) asserted that a scholar's disciplinary affiliation influences their information seeking behaviour when using traditional information sources, and Abels et.al (1996); Tenopir (2003); and Torma and Vakkari (2004) have subsequently concluded that disciplinary culture is closely associated with the way in which scholars use networked information. The differences in the use of networked information between scientists and social scientists are explained by Costa and Meadows (2000) as being based on two factors. These are firstly, the differences in information needs and types of information used by the two groups, and secondly, because scientists were using computers some time before social scientists. Support for these propositions is provided by Talja and Maula (2003), in research indicating that by 2000 most scholars in science disciplines were already high level users, while scholars of humanities disciplines were still recognised as 
low users of databases and full text e-journals. That conclusion had also been supported by Lenares (1999) who-based on a sample derived from twenty universities in the United States-found that physical and biological scientists reported higher use than humanities and social science scholars.

Applebee et al. (1998) reported on a survey of the disciplinary differences within broad classifications of the discipline groupings of sciences, arts/humanities, and social sciences. While reporting higher level of usage from science disciplines for some networked communication services, the authors indicated that it may be unreliable to associate frequency of use with academic disciplines, because frequency measures do not make it clear as to exactly how the Internet is used or what types of services are used. Therefore, the researchers assessed disciplinary differences by comparing the usefulness of e-mail for research. On that basis, it was found that science respondents indicated a more positive response than those from the social sciences or humanities.

Budd and Connaway (1997) investigated the use of networked information by sampling academics at six departments representing the three broad categories of sciences, social sciences, and humanities, and differences were examined based on respondents' departmental affiliation. When asked whether they use networked information, respondents from the departments of sociology (64\%), physics (56\%), and chemistry (52\%) indicated a majority of positive responses; whereas those from the departments of English, psychology, and history indicated a majority of negative responses. However, no significant differences were reported between respondents according to their department.

Lu (1998) investigated how "electronic vehicles" (such as a web site of a journal, e-mail address for a journal, electronic submission, electronic publishing) had impacted on formal scholarly communication by conducting a study of the communication practices of journals in both social science and natural science disciplines. The results indicated that the majority of 21 categories of "vehicles" were used more frequently in natural science disciplines than social sciences.

Heterick (2002) compared economists' and humanities scholars' attitudes towards electronic resources. The findings indicate a variance of attitudes between the two groups of scholars. For example, while almost $60 \%$ of economists consider the library's online catalog "very important", nearly $90 \%$ of humanities scholars consider this to be the case. When respondents were asked whether networked information will reduce their personal visits to the physical library, almost 54\% of the economists agreed, as compared to only $22 \%$ of those from the humanities. The results also indicate differences between the attitudes of economists and humanities scholars toward the reliability of electronically stored information. While only $24 \%$ of the economists indicated they would trust a repository of electronic information, almost $63 \%$ of the humanities scholars reported a similar level of trust.

Torma and Vakkari (2004) investigated how academics' disciplines and availability of "electronic resources" correlate with their frequency and purpose of use of electronic resources provided by the Finnish National Electronic Library (FinELib). Data were collected using an annual survey of users of the FinELib website. There were 629 respondents identified as belonging to one of six disciplinary groups. The findings indicated disciplinary differences, with respondents from the natural sciences (63\%), economists (57\%), medicine (46\%), and engineering (40\%) reporting daily use in more cases than academics from the social sciences (35\%) or humanities (34\%). However, the study found that 
"perceived availability" of electronic resources was a stronger predictor of the frequency of use than disciplinary differences.

Digital Information services provided by libraries have also been differently used by academics according to their disciplines. Borgman (2000) and Tenopir (2003) revealed that academics from science disciplines use "electronic information" sourced from academic libraries more than their counterparts from the social sciences and humanities. In the Arab World, Ibrahim (2004) investigated the use of networked information and library services at the United Arab Emirates University and reported that academics from science disciplines indicated higher use than their counterparts in the social sciences and humanities.

Costa and Meadows noted in 2000 that earlier studies conducted in the networking era indicated disciplinary differences in networked information use between scientists and social scientists, but they argued that more recent studies were suggesting that these differences had decreased as all disciplines adapted to the use of digital information and communication. Logically this might be thought to be true as researchers, irrespective of their discipline, became almost universally adept at using information and communication technologies to facilitate their research and communication. The current research therefore provided an opportunity to test the extent to which disciplines had become consistent in their use of, and attitudes towards, networked scholarship.

\section{Methodology}

The methodology selected for the research is quantitative, and the tool is a questionnaire survey. The questionnaire was developed with reference to the existing literature and the goal and objectives of the study. Before the questionnaire was distributed for the major collection of data it was piloted and also examined by expert referees. Modifications were made whenever applicable. All academics at SQU were considered probable respondents to the questionnaire, and all colleges were sampled. This approach allowed for the comparison of the results within and between different sample groups.

The questionnaire was translated from English into Arabic to allow academics who do not speak English to participate. Native Arabic speakers who also speak English were given the choice of completing an English or Arabic version. The survey was administered at SQU in December 2004. The response rate to the survey was $48 \%(n=287)$ of the 599 distributed questionnaires. The overall response rate of the whole population of SQU academics (765) was 37.5\%.

The questionnaire data were coded and entered into the Statistical Package for Social Sciences (SPSS). Both descriptive and inferential quantitative analysis were used to extract maximum information from the data. Firstly, descriptive analysis involving frequency and percentage distribution of all variables, as well as calculating mean scores whenever required; and secondly, inferential analysis for testing associations between particular variables using both parametric and nonparametric statistics. Three types of inferential statistical tests were undertaken, but only the parametric technique of One-Way Analysis of Variance (One-Way ANOVA) is reported, as the supplementary testing did not produce any variations. ANOVA is best used to investigate how several independent variables interact with each other and how these interactions affect the dependent variables (Field, 2005). In this study One-Way ANOVA was used to determine whether there were significant relationships based on differences of group means between particular variables and disciplinary differences. 
Both the Kruskal-Wallis test and Independent-Samples $\mathrm{T}$ test (results not reported) were used to verify and qualify the result of ANOVA in this study. This process enhanced the reliability and the trustworthiness of the inferential analysis. For all of the inferential analysis results, the minimum level of significance was determined at .05 .

\section{Findings}

The categorisation of disciplines in the current study has been based on the organisational structure of SQU, in which colleges have been divided into two broad disciplinary arrangements. These are humanities and social sciences as one division, and sciences as another division. The Humanities and Social Sciences Division includes three colleges; namely the Colleges of Arts and Social Sciences; Commerce and Economics, and Education. The Science Division consists of four colleges; the Colleges of Agriculture and Marine Sciences; Medicine; Engineering, and Science. Therefore, One Way ANOVA is used to determine whether there are significant differences in the respondents' opinions and attitudes according to the broad disciplinary categories associated with SQU's two Divisions.

\subsection{Use of Networked Information}

Table 1. ANOVA test of discipline versus skills, importance of use and length of use.

\begin{tabular}{|c|c|c|c|c|c|c|c|}
\hline Item & & & Sum of Squares & df & Mean Square & $\mathrm{F}$ & .Sig \\
\hline 1 & $\begin{array}{l}\text { How would you describe your skills as a } \\
\text { user of networked information? }\end{array}$ & $\begin{array}{l}\text { Betwn Groups } \\
\text { Within Groups } \\
\text { Total }\end{array}$ & $\begin{array}{c}.241 \\
85.393 \\
85.635\end{array}$ & $\begin{array}{c}1 \\
280 \\
281\end{array}$ & $\begin{array}{l}.241 \\
.305\end{array}$ & .79 & .374 \\
\hline 2 & $\begin{array}{l}\text { How important is it for you to be } \\
\text { proficient in using and applying } \\
\text { networked information? }\end{array}$ & $\begin{array}{l}\text { Betwn Groups } \\
\text { Within Groups } \\
\text { Total }\end{array}$ & $\begin{array}{l}2.060 \\
67.898 \\
69.958\end{array}$ & $\begin{array}{c}1 \\
282 \\
283\end{array}$ & $\begin{array}{c}2.060 \\
.241\end{array}$ & 8.55 & .004 \\
\hline 3 & $\begin{array}{l}\text { How long have you been using networked } \\
\text { information services? }\end{array}$ & $\begin{array}{l}\text { Betwn Groups } \\
\text { Within Groups } \\
\text { Total }\end{array}$ & $\begin{array}{c}15.717 \\
171.843 \\
187.560\end{array}$ & $\begin{array}{c}1 \\
282 \\
283\end{array}$ & $\begin{array}{c}15.717 \\
.609\end{array}$ & $\begin{array}{c}25.7 \\
9\end{array}$ & .000 \\
\hline
\end{tabular}

Participants' assessment of their proficiency in using networked information differs significantly across the disciplinary groupings. It is concluded from the ANOVA table (Table 1) that there are statistically significant differences in mean groups at .005 for items 2 and 3. Descriptive data illustrates that respondents from science disciplines consider the proficiency of using networked information is more important than do their counterparts from the humanities and social sciences. Moreover, respondents from science disciplines have been using networked information longer than respondents from humanities and social sciences. Despite these differences in perceived importance and duration of use, there was, however, no significant difference between the disciplines regarding their perception of their current level of skill in using networked information.

\subsection{Frequency of use of networked information}


Table 2. ANOVA test of discipline versus frequency of use of networked information.

\begin{tabular}{|c|c|c|c|c|c|c|c|}
\hline Item & How frequently do you use & & Sum of Squares & $\mathrm{df}$ & Mean Square & F & .Sig \\
\hline 1 & Email? & $\begin{array}{c}\text { Betwn Groups } \\
\text { Within Groups } \\
\text { Total } \square\end{array}$ & $\begin{array}{c}22.709 \\
293.298 \\
316.007\end{array}$ & $\begin{array}{c}1 \\
281 \\
282\end{array}$ & $\begin{array}{c}22.709 \\
1.044\end{array}$ & 21.75 & .000 \\
\hline 2 & Mailing Lists? & $\begin{array}{c}\text { Betwn Groups } \\
\text { Within Groups } \\
\text { Total }\end{array}$ & $\begin{array}{c}23.651 \\
950.956 \\
974.607\end{array}$ & $\begin{array}{c}1 \\
265 \\
266\end{array}$ & $\begin{array}{c}23.651 \\
3.589\end{array}$ & 6.59 & .011 \\
\hline 3 & Bulletin Boards? & $\begin{array}{c}\text { Betwn Groups } \\
\text { Within Groups } \\
\text { Total }\end{array}$ & $\begin{array}{c}.111 \\
896.798 \\
896.909\end{array}$ & $\begin{array}{c}1 \\
273 \\
274\end{array}$ & $\begin{array}{c}.111 \\
3.285\end{array}$ & .034 & .854 \\
\hline 4 & Internet Chat? & $\begin{array}{c}\text { Betwn Groups } \\
\text { Within Groups } \\
\text { Total }\end{array}$ & $\begin{array}{c}19.203 \\
660.280 \\
679.484\end{array}$ & $\begin{array}{c}1 \\
277 \\
278\end{array}$ & $\begin{array}{c}19.203 \\
2.384\end{array}$ & 8.05 & .005 \\
\hline 5 & Video Conferencing? & $\begin{array}{c}\text { Betwn Groups } \\
\text { Within Groups } \\
\text { Total }\end{array}$ & $\begin{array}{c}2.776 \\
240.742 \\
243.518\end{array}$ & $\begin{array}{c}1 \\
274 \\
275\end{array}$ & $\begin{array}{c}2.776 \\
.879\end{array}$ & 3.15 & .077 \\
\hline 6 & E-Journals? & $\begin{array}{c}\text { Betwn Groups } \\
\text { Within Groups } \\
\text { Total } \square\end{array}$ & $\begin{array}{c}7.569 \\
475.116 \\
482.686\end{array}$ & $\begin{array}{c}1 \\
281 \\
282\end{array}$ & $\begin{array}{c}2.776 \\
.879\end{array}$ & 4.47 & .035 \\
\hline 7 & Full-texts other than E-journals? & $\begin{array}{c}\text { Betwn Groups } \\
\text { Within Groups } \\
\text { Total } \square\end{array}$ & $\begin{array}{c}6.123 \\
467.342 \\
473.465\end{array}$ & $\begin{array}{c}1 \\
282 \\
283\end{array}$ & $\begin{array}{l}6.123 \\
1.657\end{array}$ & 3.69 & .056 \\
\hline 8 & Web-based Library Catalogs? & $\begin{array}{c}\text { Betwn Groups } \\
\text { Within Groups } \\
\text { Total }\end{array}$ & $\begin{array}{c}.533 \\
561.495 \\
562.028\end{array}$ & $\begin{array}{c}1 \\
281 \\
282\end{array}$ & $\begin{array}{c}.533 \\
1.998\end{array}$ & .26 & .606 \\
\hline 9 & Web-based Databases? & $\begin{array}{c}\text { Betwn Groups } \\
\text { Within Groups } \\
\text { Total } \square\end{array}$ & $\begin{array}{c}7.025 \\
621.950 \\
628.975\end{array}$ & $\begin{array}{c}1 \\
277 \\
278\end{array}$ & $\begin{array}{l}7.025 \\
2.245\end{array}$ & 3.12 & .078 \\
\hline 10 & Internet Search Engines? & $\begin{array}{c}\text { Betwn Groups } \\
\text { Within Groups } \\
\text { Total }\end{array}$ & $\begin{array}{c}5.342 \\
300.188 \\
305.530\end{array}$ & $\begin{array}{c}1 \\
279 \\
280\end{array}$ & $\begin{array}{l}5.342 \\
1.076\end{array}$ & 4.96 & .027 \\
\hline
\end{tabular}

Of the ten items listed that measure the frequency of use of networked information, five items (1, 2, 4, 6 and 10) across the disciplinary grouping of the participants are found to be statistically significant at .05 level (Table 2). Descriptive data illustrates that respondents from science disciplines use e-mail, mailing lists, Internet search engines, and e-journals more frequently than respondents from the humanities and social sciences. In contrast, respondents from humanities and social sciences disciplines use Internet chat more frequently than do their colleagues from the sciences.

\subsection{Scholarly Communication Activities}

Table 3. ANOVA test of discipline versus scholarly communication activities.

\begin{tabular}{|c|c|c|c|c|c|c|c|}
\hline Item & $\begin{array}{l}\text { Do you use networked information } \\
\text { services to: }\end{array}$ & & Sum of Squares & df & Mean Square & $\mathrm{F}$ & .Sig \\
\hline 1 & $\begin{array}{l}\text { Communicate with academics or } \\
\text { researchers at same institutions? }\end{array}$ & $\begin{array}{l}\text { Betwn Groups } \\
\text { Within Groups } \\
\quad \text { Total } \square\end{array}$ & $\begin{array}{c}35.713 \\
167.241 \\
202.954\end{array}$ & $\begin{array}{c}1 \\
281 \\
282\end{array}$ & $\begin{array}{l}35.713 \\
.595\end{array}$ & 60.00 & .000 \\
\hline 2 & $\begin{array}{l}\text { Communicate with academics or } \\
\text { researchers at different institutions in } \\
\text { Oman? }\end{array}$ & $\begin{array}{l}\text { Betwn Groups } \\
\text { Within Groups } \\
\text { Total }\end{array}$ & $\begin{array}{c}1.839 \\
274.067 \\
275.915\end{array}$ & $\begin{array}{c}1 \\
280 \\
281\end{array}$ & $\begin{array}{c}1.839 \\
.979\end{array}$ & 1.87 & .172 \\
\hline
\end{tabular}




\begin{tabular}{|c|c|c|c|c|c|c|c|}
\hline Item & $\begin{array}{l}\text { Do you use networked information } \\
\text { services to: }\end{array}$ & & Sum of Squares & df & Mean Square & $\mathrm{F}$ & Sig \\
\hline 3 & $\begin{array}{l}\text { Communicate with academics or } \\
\text { researchers at different institutions } \\
\text { within the Arab States? }\end{array}$ & $\begin{array}{l}\text { Betwn Groups } \\
\text { Within Groups } \\
\text { Total }\end{array}$ & $\begin{array}{c}1.659 \\
251.124 \\
252.784\end{array}$ & $\begin{array}{c}1 \\
280 \\
281\end{array}$ & $\begin{array}{c}1.659 \\
.897\end{array}$ & 1.85 & .175 \\
\hline 4 & $\begin{array}{l}\text { Communicate with academics or } \\
\text { researchers at different institutions } \\
\text { globally? }\end{array}$ & $\begin{array}{l}\text { Betwn Groups } \\
\text { Within Groups } \\
\text { Total }\end{array}$ & $\begin{array}{c}40.133 \\
243.357 \\
283.489\end{array}$ & $\begin{array}{c}1 \\
280 \\
281\end{array}$ & $\begin{array}{c}40.133 \\
.869\end{array}$ & 46.17 & .000 \\
\hline 5 & $\begin{array}{l}\text { Exchange documents or information } \\
\text { about issues or topics in an area of } \\
\text { research? }\end{array}$ & $\begin{array}{c}\text { Betwn Groups } \\
\text { Within Groups } \\
\text { Total }\end{array}$ & $\begin{array}{c}15.087 \\
248.360 \\
263.447\end{array}$ & $\begin{array}{c}1 \\
282 \\
283\end{array}$ & $\begin{array}{c}15.087 \\
.881\end{array}$ & 17.13 & .000 \\
\hline 6 & Obtain bibliographic references? & $\begin{array}{l}\text { Betwn Groups } \\
\text { Within Groups } \\
\text { Total }\end{array}$ & $\begin{array}{c}4.853 \\
214.551 \\
219.404\end{array}$ & $\begin{array}{c}1 \\
280 \\
281\end{array}$ & $\begin{array}{c}4.853 \\
.766\end{array}$ & 6.33 & .012 \\
\hline 7 & Provide or obtain updates on research? & $\begin{array}{l}\text { Betwn Groups } \\
\text { Within Groups } \\
\text { Total }\end{array}$ & $\begin{array}{c}9.621 \\
211.397 \\
221.018\end{array}$ & $\begin{array}{c}1 \\
279 \\
280\end{array}$ & $\begin{array}{c}9.621 \\
.758\end{array}$ & 12.69 & .000 \\
\hline 8 & Ask questions or provide answers? & $\begin{array}{c}\text { Betwn Groups } \\
\text { Within Groups } \\
\text { Total }\end{array}$ & $\begin{array}{c}12.056 \\
221.590 \\
233.645\end{array}$ & $\begin{array}{c}1 \\
280 \\
281\end{array}$ & $\begin{array}{c}12.056 \\
.791\end{array}$ & 15.23 & .000 \\
\hline 9 & Keep current in an area of research & $\begin{array}{c}\text { Betwn Groups } \\
\text { Within Groups } \\
\text { Total }\end{array}$ & $\begin{array}{c}4.711 \\
188.243 \\
192.954\end{array}$ & $\begin{array}{c}1 \\
281 \\
282\end{array}$ & $\begin{array}{c}4.711 \\
.670\end{array}$ & 7.03 & .008 \\
\hline 10 & $\begin{array}{l}\text { Learn about conference } \\
\text { announcements? }\end{array}$ & $\begin{array}{c}\text { Betwn Groups } \\
\text { Within Groups } \\
\text { Total }\end{array}$ & $\begin{array}{c}4.808 \\
200.389 \\
205.197\end{array}$ & $\begin{array}{c}1 \\
282 \\
283\end{array}$ & $\begin{array}{c}4.808 \\
.711\end{array}$ & 6.76 & .010 \\
\hline 11 & Communicate with publishers & $\begin{array}{c}\text { Betwn Groups } \\
\text { Within Groups } \\
\text { Total }\end{array}$ & $\begin{array}{c}52.998 \\
264.284 \\
317.281\end{array}$ & $\begin{array}{c}1 \\
279 \\
280\end{array}$ & $\begin{array}{c}52.998 \\
.947\end{array}$ & 55.94 & .000 \\
\hline
\end{tabular}

The ANOVA test reported in Table 3 reveals that of the above listed scholarly communication activities, nine items (all items except 2 and 3) differ significantly as a function of disciplinary affiliation at .05 level. The descriptive data illustrates that respondents from science disciplines indicated more positive responses for all above scholarly communication activities than respondents from humanities and social science disciplines.

\subsection{Impact of Networked Information}

Table 4. ANOVA test of discipline versus impact of networked information.

\begin{tabular}{|c|c|c|c|c|c|c|c|}
\hline Item & Impact of Networked Information & & Sum of Squares & df & $\begin{array}{l}\text { Mean } \\
\text { Square }\end{array}$ & $\mathrm{F}$ & .Sig \\
\hline 1 & I enjoy using networked information. & $\begin{array}{l}\text { Betwn Groups } \\
\text { Within Groups } \\
\text { Total } \square\end{array}$ & $\begin{array}{c}.163 \\
145.625 \\
145.788\end{array}$ & $\begin{array}{c}1 \\
280 \\
282\end{array}$ & $\begin{array}{l}.163 \\
.518\end{array}$ & .315 & .575 \\
\hline 2 & $\begin{array}{l}\text { Networked information makes it easier for } \\
\text { me to research and publish collaboratively. }\end{array}$ & $\begin{array}{l}\text { Betwn Groups } \\
\text { Within Groups } \\
\text { Total }\end{array}$ & $\begin{array}{c}3.849 \\
132.620 \\
136.468\end{array}$ & $\begin{array}{c}1 \\
280 \\
281\end{array}$ & $\begin{array}{c}3.849 \\
.474\end{array}$ & 8.12 & .005 \\
\hline 3 & $\begin{array}{l}\text { Networked information has helped me } \\
\text { access new tools for my research and } \\
\text { scholarly communication. }\end{array}$ & $\begin{array}{l}\text { Betwn Groups } \\
\text { Within Groups } \\
\text { Total } \square\end{array}$ & $\begin{array}{c}.042 \\
151.550 \\
151.592\end{array}$ & $\begin{array}{c}1 \\
280 \\
281\end{array}$ & $\begin{array}{l}.042 \\
.541\end{array}$ & .078 & .780 \\
\hline 4 & $\begin{array}{l}\text { Networked information provides me with } \\
\text { the capabilities to easily work beyond } \\
\text { geographic boundaries. }\end{array}$ & $\begin{array}{l}\text { Betwn Groups } \\
\text { Within Groups } \\
\text { Total } \square\end{array}$ & $\begin{array}{c}1.695 \\
169.273 \\
170.968\end{array}$ & $\begin{array}{c}1 \\
282 \\
283\end{array}$ & $\begin{array}{c}1.695 \\
.600\end{array}$ & 2.82 & .094 \\
\hline
\end{tabular}




\begin{tabular}{|c|c|c|c|c|c|c|c|}
\hline Item & Impact of Networked Information & & Sum of Squares & df & $\begin{array}{l}\text { Mean } \\
\text { Square }\end{array}$ & $\mathrm{F}$ & .Sig \\
\hline 5 & $\begin{array}{l}\text { Networked information has helped me } \\
\text { establish new relations with other } \\
\text { researchers. }\end{array}$ & $\begin{array}{l}\text { Betwn Groups } \\
\text { Within Groups } \\
\text { Total } \square\end{array}$ & $\begin{array}{c}10.636 \\
209.761 \\
220.396\end{array}$ & $\begin{array}{c}1 \\
278 \\
279\end{array}$ & $\begin{array}{c}10.636 \\
.755\end{array}$ & $\begin{array}{c}14.0 \\
9\end{array}$ & .000 \\
\hline 6 & $\begin{array}{l}\text { The use of networked information will } \\
\text { increase my number of publications over } \\
\text { the next few years. }\end{array}$ & $\begin{array}{l}\text { Betwn Groups } \\
\text { Within Groups } \\
\text { Total } \square\end{array}$ & $\begin{array}{c}1.964 \\
215.167 \\
217.131\end{array}$ & $\begin{array}{c}1 \\
281 \\
282\end{array}$ & $\begin{array}{c}1.964 \\
.766\end{array}$ & 2.56 & .110 \\
\hline 7 & $\begin{array}{l}\text { The use of networked information will } \\
\text { improve the quality of my research over } \\
\text { the next few years. }\end{array}$ & $\begin{array}{l}\text { Betwn Groups } \\
\text { Within Groups } \\
\quad \text { Total } \square\end{array}$ & $\begin{array}{c}1.907 \\
193.417 \\
195.324\end{array}$ & $\begin{array}{c}1 \\
282 \\
283\end{array}$ & $\begin{array}{c}1.907 \\
.686\end{array}$ & 2.78 & .097 \\
\hline 8 & $\begin{array}{l}\text { Some of my research will be published } \\
\text { electronically over the next few years. }\end{array}$ & $\begin{array}{l}\text { Betwn Groups } \\
\text { Within Groups } \\
\text { Total } \square\end{array}$ & $\begin{array}{c}.124 \\
191.819 \\
191.943\end{array}$ & $\begin{array}{c}1 \\
280 \\
281\end{array}$ & $\begin{array}{l}.124 \\
.685\end{array}$ & .181 & .671 \\
\hline 9 & $\begin{array}{l}\text { Networked information will widen the } \\
\text { scholarly community within which I am in } \\
\text { contact over the next few years. }\end{array}$ & $\begin{array}{l}\text { Betwn Groups } \\
\text { Within Groups } \\
\text { Total } \square\end{array}$ & $\begin{array}{c}.078 \\
132.791 \\
132.869\end{array}$ & $\begin{array}{c}1 \\
280 \\
281\end{array}$ & $\begin{array}{l}.078 \\
.474\end{array}$ & .164 & .686 \\
\hline 10 & $\begin{array}{l}\text { I will become increasingly dependent on } \\
\text { networked information over the next few } \\
\text { years. }\end{array}$ & $\begin{array}{l}\text { Betwn Groups } \\
\text { Within Groups } \\
\text { Total } \square\end{array}$ & $\begin{array}{c}1.357 \\
208.163 \\
209.519\end{array}$ & $\begin{array}{c}1 \\
281 \\
282\end{array}$ & $\begin{array}{c}1.357 \\
.741\end{array}$ & 1.83 & .177 \\
\hline
\end{tabular}

Among a list of items that investigated the impact of networked information on research and scholarly communication, only two items (2 and 5) were found to differ significantly across the participants' disciplinary groupings at 05 level (Table 4.). Descriptive data illustrates that respondents from science disciplines indicated more positive responses for the two significant items than do participants from humanities and social science disciplines. These results support the commonly held view that science scholars are more likely to form research teams than those in other disciplines. They also indicate that they have adopted the use of networked information sources to assist in this regard.

\subsection{Training and Library Support}

Table 5. ANOVA test of discipline versus training and library support.

\begin{tabular}{|c|c|c|c|c|c|c|c|}
\hline Item & Training and Library Support & & $\begin{array}{l}\text { Sum of } \\
\text { Squares }\end{array}$ & df & Mean Square & $\mathrm{F}$ & Sig \\
\hline 1 & $\begin{array}{l}\text { I am able to access all networked information } \\
\text { from my office or lab. }\end{array}$ & $\begin{array}{l}\text { Betwn Groups } \\
\text { Within Groups } \\
\quad \text { Total }\end{array}$ & $\begin{array}{c}.008 \\
265.586 \\
265.594\end{array}$ & $\begin{array}{c}1 \\
279 \\
280\end{array}$ & $\begin{array}{l}.008 \\
.952\end{array}$ & .009 & .925 \\
\hline 2 & $\begin{array}{l}\text { The university runs training sessions for } \\
\text { faculty members to use networked } \\
\text { information. }\end{array}$ & $\begin{array}{l}\text { Betwn Groups } \\
\text { Within Groups } \\
\quad \text { Total }\end{array}$ & $\begin{array}{c}.684 \\
214.313 \\
214.996\end{array}$ & $\begin{array}{c}1 \\
278 \\
279\end{array}$ & $\begin{array}{l}.684 \\
.771\end{array}$ & .887 & .347 \\
\hline 3 & $\begin{array}{l}\text { The University commitment to improving the } \\
\text { process of electronic scholarly } \\
\text { communication is highly appreciated. }\end{array}$ & $\begin{array}{l}\text { Betwn Groups } \\
\text { Within Groups } \\
\quad \text { Total }\end{array}$ & $\begin{array}{c}3.004 \\
195.496 \\
198.500\end{array}$ & $\begin{array}{c}1 \\
278 \\
279\end{array}$ & $\begin{array}{c}3.004 \\
.703\end{array}$ & 4.27 & .040 \\
\hline 4 & $\begin{array}{l}\text { The library website is easy to navigate and } \\
\text { gives comprehensive instructions and } \\
\text { information. }\end{array}$ & $\begin{array}{l}\text { Betwn Groups } \\
\text { Within Groups } \\
\quad \text { Total }\end{array}$ & $\begin{array}{c}6.599 \\
260.493 \\
267.092\end{array}$ & $\begin{array}{c}1 \\
280 \\
281\end{array}$ & $\begin{array}{c}6.599 \\
.930\end{array}$ & 7.09 & .008 \\
\hline 5 & $\begin{array}{l}\text { The availability of networked information } \\
\text { resources at the library is sufficient. }\end{array}$ & $\begin{array}{c}\text { Betwn Groups } \\
\text { Within Groups } \\
\text { Total }\end{array}$ & $\begin{array}{c}23.509 \\
242.881 \\
266.390\end{array}$ & $\begin{array}{c}1 \\
275 \\
276\end{array}$ & $\begin{array}{l}23.509 \\
.883\end{array}$ & 26.6 & .000 \\
\hline 6 & $\begin{array}{l}\text { The library's web-based catalog is clear and } \\
\text { easy to use. }\end{array}$ & $\begin{array}{c}\text { Betwn Groups } \\
\text { Within Groups } \\
\text { Total }\end{array}$ & $\begin{array}{c}7.771 \\
222.000 \\
229.771\end{array}$ & $\begin{array}{c}1 \\
278 \\
279\end{array}$ & $\begin{array}{c}7.771 \\
.799\end{array}$ & 9.73 & .002 \\
\hline 7 & $\begin{array}{l}\text { E-journals in my field are adequate and } \\
\text { useful. }\end{array}$ & $\begin{array}{c}\text { Betwn Groups } \\
\text { Within Groups } \\
\text { Total }\end{array}$ & $\begin{array}{c}1.938 \\
352.177 \\
354.115\end{array}$ & $\begin{array}{c}1 \\
276 \\
277\end{array}$ & $\begin{array}{l}1.938 \\
1.276\end{array}$ & 1.51 & .219 \\
\hline
\end{tabular}




\begin{tabular}{|c|c|c|c|c|c|c|c|}
\hline Item & Training and Library Support & & $\begin{array}{l}\text { Sum of } \\
\text { Squares }\end{array}$ & df & Mean Square & $\mathrm{F}$ & Sig \\
\hline 8 & $\begin{array}{l}\text { Computer facilities and equipment in the } \\
\text { library are adequate. }\end{array}$ & $\begin{array}{l}\text { Betwn Groups } \\
\text { Within Groups } \\
\text { Total }\end{array}$ & $\begin{array}{c}.461 \\
235.506 \\
235.968\end{array}$ & $\begin{array}{c}1 \\
278 \\
279\end{array}$ & $\begin{array}{l}.461 \\
847\end{array}$ & .545 & .461 \\
\hline 9 & $\begin{array}{l}\text { I receive updates from the library through a } \\
\text { networked medium such group mailing lists. }\end{array}$ & $\begin{array}{l}\text { Betwn Groups } \\
\text { Within Groups } \\
\text { Total }\end{array}$ & $\begin{array}{c}13.827 \\
371.808 \\
385.635\end{array}$ & $\begin{array}{c}1 \\
280 \\
281\end{array}$ & $\begin{array}{c}13.827 \\
1.328\end{array}$ & 10.4 & .001 \\
\hline 10 & $\begin{array}{l}\text { The library informs me about networked } \\
\text { information resources and services that are } \\
\text { newly available. }\end{array}$ & $\begin{array}{l}\text { Betwn Groups } \\
\text { Within Groups } \\
\text { Total }\end{array}$ & $\begin{array}{c}.166 \\
367.851 \\
368.018\end{array}$ & $\begin{array}{c}1 \\
280 \\
281\end{array}$ & $\begin{array}{l}.166 \\
1.314\end{array}$ & .127 & .722 \\
\hline 11 & $\begin{array}{l}\text { The library invites me to attend sessions on } \\
\text { networked information. }\end{array}$ & $\begin{array}{l}\text { Betwn Groups } \\
\text { Within Groups } \\
\text { Total }\end{array}$ & $\begin{array}{c}.242 \\
292.320 \\
292.562\end{array}$ & $\begin{array}{c}1 \\
279 \\
280\end{array}$ & $\begin{array}{c}.242 \\
1.048\end{array}$ & .231 & .631 \\
\hline 12 & Librarians are very collaborative and helpful. & $\begin{array}{l}\text { Betwn Groups } \\
\text { Within Groups } \\
\text { Total }\end{array}$ & $\begin{array}{c}4.486 \\
211.710 \\
216.196\end{array}$ & $\begin{array}{c}1 \\
278 \\
279\end{array}$ & $\begin{array}{l}4.486 \\
.762\end{array}$ & 5.89 & .016 \\
\hline 13 & $\begin{array}{l}\text { I am overall satisfied about the networked } \\
\text { information services facilitated by the library. }\end{array}$ & $\begin{array}{c}\text { Betwn Groups } \\
\text { Within Groups } \\
\text { Total } \square\end{array}$ & $\begin{array}{c}11.649 \\
240.152 \\
251.801\end{array}$ & $\begin{array}{c}1 \\
279 \\
280\end{array}$ & $\begin{array}{c}11.649 \\
.861\end{array}$ & 13.5 & .000 \\
\hline
\end{tabular}

It is concluded from the above ANOVA table (Table 5) that the respondents' attitudes to training and library support differ significantly according to disciplinary groupings at .05 for items $3,4,5,6,9,12$, and 13 . The descriptive data illustrates that participants from humanities and social science disciplines indicated more positive responses to those statically significant items than respondents from the sciences.

\subsection{Perception of Arabic as a Scholarly Language}

Table 6. ANOVA test of discipline versus academics’ perception.

\begin{tabular}{|c|c|c|c|c|c|c|c|}
\hline Item & $\begin{array}{c}\text { Perception of Arabic as a scholarly } \\
\text { Language }\end{array}$ & & Sum of Squares & df & Mean Square & F & .Sig \\
\hline 1 & $\begin{array}{l}\text { The availability of networked information in } \\
\text { English substitutes for the shortage of } \\
\text { networked information in Arabic. }\end{array}$ & $\begin{array}{l}\text { Betwn Groups } \\
\text { Within Groups } \\
\text { Total }\end{array}$ & $\begin{array}{c}1.707 \\
275.813 \\
277.520\end{array}$ & $\begin{array}{c}1 \\
198 \\
199\end{array}$ & $\begin{array}{l}1.707 \\
1.393\end{array}$ & 1.225 & .270 \\
\hline 2 & $\begin{array}{l}\text { Sufficient availability of Arabic networked } \\
\text { information would have increased my } \\
\text { intellectual productivity. }\end{array}$ & $\begin{array}{l}\text { Betwn Groups } \\
\text { Within Groups } \\
\text { Total }\end{array}$ & $\begin{array}{l}12.783 \\
210.880 \\
223.663\end{array}$ & $\begin{array}{c}1 \\
200 \\
201\end{array}$ & $\begin{array}{c}12.783 \\
1.054\end{array}$ & 12.12 & .001 \\
\hline 3 & $\begin{array}{l}\text { Sufficient availability of Arabic networked } \\
\text { information would have encouraged me to } \\
\text { think about publishing more in Arabic. }\end{array}$ & $\begin{array}{l}\text { Betwn Groups } \\
\text { Within Groups } \\
\text { Total }\end{array}$ & $\begin{array}{c}31.448 \\
225.448 \\
256.896\end{array}$ & $\begin{array}{c}1 \\
200 \\
201\end{array}$ & $\begin{array}{c}31.448 \\
1.127\end{array}$ & 27.89 & .000 \\
\hline 4 & $\begin{array}{l}\text { Sufficient availability of Arabic networked } \\
\text { information would help me to remain } \\
\text { current in my field. }\end{array}$ & $\begin{array}{l}\text { Betwn Groups } \\
\text { Within Groups } \\
\text { Total }\end{array}$ & $\begin{array}{l}35.364 \\
241.745 \\
277.109\end{array}$ & $\begin{array}{c}1 \\
200 \\
201\end{array}$ & $\begin{array}{c}35.364 \\
1.209\end{array}$ & 29.25 & .000 \\
\hline 5 & $\begin{array}{l}\text { Teaching and learning in Arabic within my } \\
\text { discipline is difficult due to the lack of } \\
\text { networked information in Arabic. }\end{array}$ & $\begin{array}{l}\text { Betwn Groups } \\
\text { Within Groups } \\
\text { Total }\end{array}$ & $\begin{array}{c}2.581 \\
244.703 \\
247.284\end{array}$ & $\begin{array}{c}1 \\
199 \\
200\end{array}$ & $\begin{array}{l}2.581 \\
1.230\end{array}$ & 2.099 & .149 \\
\hline 6 & $\begin{array}{l}\text { I encourage colleagues and students to use } \\
\text { English in writing and publishing. }\end{array}$ & $\begin{array}{l}\text { Betwn Groups } \\
\text { Within Groups } \\
\text { Total }\end{array}$ & $\begin{array}{c}11.255 \\
184.446 \\
195.701\end{array}$ & $\begin{array}{c}1 \\
199 \\
200\end{array}$ & $\begin{array}{c}11.255 \\
.927\end{array}$ & 12.14 & .001 \\
\hline 7 & $\begin{array}{l}\text { Learning the fields of sciences and } \\
\text { technology in Arabic will risk the learners' } \\
\text { academic and career future. }\end{array}$ & $\begin{array}{l}\text { Betwn Groups } \\
\text { Within Groups } \\
\text { Total }\end{array}$ & $\begin{array}{c}12.243 \\
225.010 \\
237.253\end{array}$ & $\begin{array}{c}1 \\
196 \\
197\end{array}$ & $\begin{array}{c}12.243 \\
1.148\end{array}$ & 10.66 & .001 \\
\hline
\end{tabular}




\begin{tabular}{|c|c|c|c|c|c|c|c|}
\hline Item & $\begin{array}{l}\text { Perception of Arabic as a scholarly } \\
\text { Language }\end{array}$ & & Sum of Squares & df & Mean Square & F & .Sig \\
\hline 8 & $\begin{array}{l}\text { Absence of Arabic E-journals and Arabic } \\
\text { networked information why Arab academics } \\
\text { favour English. }\end{array}$ & $\begin{array}{c}\text { Betwn Groups } \\
\text { Within Groups } \\
\text { Total }\end{array}$ & $\begin{array}{c}2.201 \\
229.112 \\
231.313\end{array}$ & $\begin{array}{c}1 \\
199 \\
200\end{array}$ & $\begin{array}{l}2.201 \\
1.151\end{array}$ & 1.912 & .168 \\
\hline 9 & $\begin{array}{l}\text { Without being electronically available, } \\
\text { Arabic language will not be able to } \\
\text { contribute to human and scientific } \\
\text { development. }\end{array}$ & $\begin{array}{l}\text { Betwn Groups } \\
\text { Within Groups } \\
\text { Total }\end{array}$ & $\begin{array}{c}.828 \\
329.635 \\
330.463\end{array}$ & $\begin{array}{c}1 \\
201 \\
202\end{array}$ & $\begin{array}{l}.828 \\
1.640\end{array}$ & .505 & .478 \\
\hline 10 & $\begin{array}{l}\text { The domination of English language will } \\
\text { lead to the decline of Arabic language for } \\
\text { academic purposes. }\end{array}$ & $\begin{array}{l}\text { Betwn Groups } \\
\text { Within Groups } \\
\text { Total }\end{array}$ & $\begin{array}{c}2.579 \\
319.005 \\
321.584\end{array}$ & $\begin{array}{c}1 \\
200 \\
201\end{array}$ & $\begin{array}{l}2.579 \\
1.595\end{array}$ & 1.617 & .205 \\
\hline 11 & $\begin{array}{l}\text { The presence of Arabic networked } \\
\text { information on the Internet will improve to a } \\
\text { great extent in the next few years. }\end{array}$ & $\begin{array}{l}\text { Betwn Groups } \\
\text { Within Groups } \\
\text { Total }\end{array}$ & $\begin{array}{c}1.619 \\
127.130 \\
128.749\end{array}$ & $\begin{array}{c}1 \\
201 \\
202\end{array}$ & $\begin{array}{l}1.619 \\
.632\end{array}$ & 2.560 & .111 \\
\hline 12 & $\begin{array}{l}\text { I would prefer to write and publish in Arabic } \\
\text { if the language was sufficiently available in } \\
\text { a networked environment. }\end{array}$ & $\begin{array}{l}\text { Betwn Groups } \\
\text { Within Groups } \\
\text { Total }\end{array}$ & $\begin{array}{c}25.681 \\
231.670 \\
257.351\end{array}$ & $\begin{array}{c}1 \\
200 \\
201\end{array}$ & $\begin{array}{c}25.681 \\
1.158\end{array}$ & 22.17 & .000 \\
\hline
\end{tabular}

Respondents' perception of Arabic as a scholarly language revealed statistically significant differences in group means at .005 level for six items (2, 3, 4, 6, 7, and 12) in Table 6.

It should be noted that all the colleges in the Science Division teach their programs in English, while colleges in the Humanities and Social Sciences Division teach in Arabic, with the exception of the College of Commerce and Economics which teaches in English. It is therefore apparent that the responses to statements in Table 6 correlate not only with discipline but also with the language used for teaching and research. The first three statistically significant statements (2, 3, and 4), all of which address the issue of sufficiency of "Arabic networked information" reflect the greater reliance on Arabic by social science and humanities scholars. Statements 6 and 7, which address the importance or need to use English (or languages other than Arabic) recorded a significantly more positive response from the science scholars. Interestingly, the science-based respondents also indicated (more than their colleagues in other disciplines) that they would "prefer to write and publish in Arabic if the language was sufficiently available in a networked environment”. This strongly suggests that the use of English is a choice that is made for them by the ubiquitous use of English for science communication.

\section{Discussion}

As indicated previously, categorisation of disciplines in this study has been based on the organisational structure of SQU, in which colleges have been divided according to the broad disciplinary arrangement of the humanities and social sciences in one Division, and the sciences in another Division. The purpose of this section is to discuss the use of networked information at SQU from a multidisciplinary perspective, in which the two broad disciplinary categories used by the University for administrative purposes are compared.

In general terms the results from this study indicate that science scholars at SQU are significantly more active users of networked information than their social science and humanities colleagues. The results reported in Tables 2, 3, and 4 in particular indicate the extent to which science respondents are more heavily engaged in the use of networked information for research purposes. These tables record a statistically significant difference in response by discipline for a variety of activities 
that are essential components of research productivity. These results reflect disciplinary differences regarding the use of, and attitudes towards, networked information at SQU, and can therefore be compared to results from similar studies conducted elsewhere. It is also the case, however, that such comparisons need to be undertaken with caution, as the results may reflect not only differences in the research and scholarly communication based on disciplinary characteristics, but may also be indicative of particular aspects of socio-educational development in Oman and Arab countries more generally. These additional factors include the state of the Arabic language as a means of scholarly communication, and the level of development of an effective research culture in developing Arab countries.

The United Nations Development Programme in its influential Arab Human Development Report (2003) pointed to the "crisis of the Arabic language" (p. 122) when used for scholarly purposes and called for the "Arabization" of university education—particularly science education—in the Middle-East region. The Report noted the domination of English for use in scholarly communication, and the failure-due to a series of socio-political and technical issues - to adapt Arabic for scholarly use in the digital environment. For these reasons Arab scholars' attitudes towards the use of the two languages for teaching and research purposes are of great importance. As noted previously disciplines and language are currently closely aligned at SQU and the results reported in Table 6 seemingly reflect the different experience of respondents who teach and research in English (from the sciences) and those who use Arabic (from the social sciences and humanities). The results recording the significantly lesser reliance by social science and humanities scholars on networked sources of information are likely to be indicative of the underrepresentation of Arabic on the Internet and in other digitised information sources. It should also be noted that the results may point to the uncertain attitude towards the two languages held by science scholars, whereby they recognise the necessity of using English while retaining a preference for Arabic. The issue of language in the comparative use of Arabic and English for communication of Arab scholarship has been discussed by Al-Aufi (2006).

The Arab Human Development Report also argued that Arab humanities and social science scholars have been working in a vacuum, as their disciplinary networks and communities are poorly formed. This claim is supported by the results of the current study, with respondents from the humanities and social sciences reporting that they communicate with colleagues less frequently than respondents from the science disciplines, and that they have been less successful in working "collaboratively" or establishing "new relations". It can be speculated that science scholars, due to their use of English and the more international focus of science research, have been able to make use of networked communication to attach themselves to established international research communities. This is apparently not the case, however, for the social sciences and humanities wherein scholarship is frequently limited by a local or regional focus and further confined by the use of Arabic. As a result such collaborative communities are less developed for these disciplines, and even opportunities for regional networking appear to be limited. Whereas collaborative research cultures have generally been slower to develop in the social sciences and (particularly) the humanities, the evidence suggests that this is particularly the case in Arab countries.

As noted, earlier studies (Abels et al., 1996; Tenopir, 2003; Torma and Vakkari, 2004) conducted in developed countries recorded similar differences between disciplines in a networked environment, but more recent studies have suggested that 
the disciplinary 'gap' in the use of networked information might be closing (Costa and Meadows, 2000). The current study contradicts this trend as disciplinary differences are still strongly indicated in the use of networked information at SQU, suggesting that there is a 'lag' in closing this gap. This is possibly due to the comparatively late uptake of networking technology at SQU-and elsewhere in the Arab world-but may also be due to the issues associated with language and underdeveloped research cultures.

An unexpected element of the results is that social science and humanities respondents reported a more positive response to the networked services provided by the SQU Library (Table 5, item 13), when other elements of the results indicate that social science and humanities respondents use these resources less than their science counterparts, and also report being comparatively dissatisfied with the level of these resources available in their preferred language (Arabic). It is therefore likely that this result reflects a greater dependence on library services and support within these disciplines, and that their generally higher level of satisfaction with other aspects of library services (also reported in Table 5) has been extended to "networked information services".

The extent to which the results from this study might be extrapolated to other Arab countries, or developing countries more generally, is also relevant. It can be hypothesised that as other Arab countries in the Persian Gulf region share similar circumstances in terms of the development of their higher education, research and communication infrastructure that they may demonstrate similar results. They also experience many of the same social and linguistic circumstances that contextualise the results of this study. It would be less safe to assume the results would be replicated in other Arab countries (for example those of the Maghreb region), or to developing countries more generally.

\section{Conclusion}

The research reported above indicates that science scholars at SQU are more dependent on networked information that those from the social sciences and humanities. This situation likely reflects differences that are intrinsic to the nature of scholarship within the disciplines and have previously been reported with regard to more 'traditional' forms of scholarship. While other research suggests that these differences might be reduced within a networked environment there is little indication that this had occurred at SQU at the time this research was conducted. It is concluded that this may be due in part to the comparatively recent uptake of networking technologies in Oman, but it is also likely to reflect aspects of the current state of scholarship in developing Arab countries, in particular the poor utilisation of Arabic in digital information environments and the lack of developed research cultures. In both respects the results from this study indicate that scholars in the social sciences and humanities are disadvantaged in a manner which is likely to negatively impact on their use of networked services for research and communication.

Additional research is required in developing Arab countries in order to understand more about the particular circumstances faced by scholars when using networked information services. This research could focus on the educational and social contexts in which the technology is deployed, in order to better understand their impact on research productivity in different disciplines.

The conclusions of this study also have implications for the development and implementation of digital library services aimed at optimising the research 
productivity of Oman and other developing Arab countries. In particular academic librarians need to develop strategies to provide scholars-particularly those working in the social sciences and humanities-with support in compiling and accessing digitised Arabic resources; and to assist in using networking technologies to build and sustain regional research communities for these same disciplines.

\section{References}

Abdulaziz, T. O. (2005), "Benefits of the Internet for Egyptian social science academics", Majallat Maktabat Almalik Fahad Alwataniyya (Journal of King Fahad National Library), Vol. 11 No 1, pp. 179-222 (source in Arabic).

Abdullah, N. M. (1999), "Faculty members' attitudes toward the Internet at Cairo University", Aalam Alma'lomat Walmaktabat Walnashir (World of Information, Libraries, and Publishing), Vol. 1 No. 1, pp. 81-106 (source in Arabic).

Abels, E. G., Liebscher, P. and Denman, D. W. (1996), "Factors that influence the use of electronic networks by science and engineering faculty at small institutions. Part I, Queries", Journal of the American Society for Information Science, Vol. 47 No 2, pp. 146-158.

Abels, E. G., Liebscher, P. and Denman, D. W. (1997), "Factors that influence the use of electronic networks by science and engineering faculty at small institutions. Part II, Preliminary Use Indicators", Journal of the American Society for Information Science, Vol. 48 No. 6, pp. 496-507.

Adika, G. (2003), "Internet use among faculty members of universities in Ghana", Library Review, Vol. 52 No 1, pp. 29-37.

Al-Ansari, H. (2006). "Internet use by the faculty members of Kuwait University". The Electronic library, Vol. 24 No 6, pp. 791-803.

Al-Aufi, A. (2006), "Transforming Information Societies: Report on survey investigating the use of the networked information for research and scholarly communication at SQU, Oman", Intercultural Communication Studies, Vol. 15 No 2, pp. 135-149.

Applebee, A., Bruce, H., Clayton, P., Pascoe, C. and Sharpe, E. (1998), Academics Online: A Nationwide Quantitative Study of Australian Academic Use of the Internet, Auslib Press, Adelaide.

Applebee, A., Clayton, P. and Pascoe, C. (1997), "Australian Academic Use of the Internet", Internet Research: Electronic Networking Applications and Policy, Vol. 7 No 2, pp. 85-94.

Bailey, C. W. (1994), "Scholarly electronic publishing on the Internet, the NREN, and the NII: charting possible futures", Serials Review, Vol. 20 No 3, pp. 7-16.

Bane, A. F. and Milheim, W. D. (1995), "Internet insights: how academics are using the Internet", Computers in Libraries, Vol. 15 No 2, pp. 32-36.

Bin-Alsabti, A. (2003), "Electronic exchange of information among academic researchers at Mentouri University of Constantine", Alarabiyya 3000 (The Arabic 3000), No 1 (source in Arabic). 
Bishop, A. P. (1994), "The role of computer networks in aerospace engineering", Library Trends, Vol. 42 No 4, pp. 694-729.

Borgman, C. L. (2000), "Digital libraries and the continuum of scholarly communication", Journal of Documentation, Vol. 56 No 4, pp. 412-430.

Boumarafi, B. M. (2001), "Use of the Internet by faculty members at Al-Sharjah University", Rissalat Almaktaba (Library Message), No. 36, pp. 111-116 (source in Arabic).

Brown, C. D. (2001), "The role of computer-mediated communication in the research process of music scholars: an exploratory investigation. Information Research, 6.

Budd, J. M. and Connaway, L. S. (1997), "University faculty and networked information: results of a survey", Journal of the American Society for Information Science, Vol. 48 No 9, pp. 843-852.

Cohen, B. (1993), "An analysis of interactions between the natural sciences and the social sciences", in Cohen, B. (Ed.), The Natural Sciences and the Social Sciences: Some Critical and Historical Perspectives, Kluwer Academic, Dordrecht, pp. 1-90.

Costa, S. and Meadows, J. (2000), "The impact of computer usage on Ssholarly communication among social scientists", Journal of Information Science, Vol. 26, pp. 255-262.

Ehikhamenor, F. A. (2003), "Internet facilities: use and non-use by Nigerian university scientists", Journal of Information Science, Vol. 29 No 1, pp. 35-48.

Eisend, M. (2002), "The Internet as a new medium for the sciences: the effects of Internet use on traditional scientific communication media among social scientists in Germany", Online Information Review, Vol. 26 No 5, pp. 307-317.

Field, A. (2005), Discovering Statistics Using SPSS (2nd ed.), SAGE, London

Garvey, W. (1979), Communication: The Essence of Science, Pergamon, Oxford.

Garvey, W. D., Tomita, K. and Woolf, P. (1974), "The dynamic scientific information user", Information Storage and Retrieval, Vol. 10 Nos 3/4, pp. 115131.

Gleaves, E. S. (1961), Characteristics of the Research Materials Used by Scholars who Write in Journals in the Field of American Literature, Unpublished Master's Thesis, Emory University, Atlanta.

Heterick, B. (2002), "E-content: faculty attitudes toward electronic resources", Educause Review, Vol. 37 No 4, pp. 10-11.

Houghton, J. W., Steele, C. and Henty, M. (2003), Changing Research Practices in the Digital Information and Communication Environment, Commonwealth of Australia, Canberra.

Ibrhaim, A. E. (2004), "Use and user perception of electronic resources in the United Arab Emirates University (UAEU)", Libri, Vol. 54 No 11, pp. 18-29.

Jirjees, J. M. and Nashir, A. (1999), "Use of the Internet by faculty members of the Yemeni Universities in Sana'a City", in AFLI (Ed.), The United Arabic Strategy 
for Information in the Era of the Internet and Other Studies, The Arab Federation for Libraries and Information (AFLI), Beirut (source in Arabic).

Kaminer, N. (1997), "Scholars and the use of the Internet", Library and Information Science Research, Vol. 19 No 4, pp. 329-345.

Lazinger, S. S., Bar-Ilan, J. and Peritz, B. C. (1997), "Internet use by faculty members in various disciplines: a comparative case study", Journal of the American Society for Information Science, Vol. 48 No 6, pp. 508-518.

Lenares, D. (1999), "Faculty Use of Electronic journals at research institutions", paper presented at the 9th National Conference of the Association of College and Research Libraries, 9 April 1999, Detroit, Michigan.

Line, M. B. (1971), "The information uses and needs of social scientists: an overview of INFROSS", ASLIB Proceedings, Vol. 23 No 8, pp. 412-434.

Lu, S. (1998), "A cross sectional study of the impact of the Internet on formal scholarly communication", paper presented at the Information Access in the Global Information Economy, 25-29 October, Pittsburgh, Pennsylvania.

Mamtora, J. (2004), "Pacific academics and the Internet", Australian Academic and Research Libraries, Vol. 35 No 1, pp. 35-52.

Meadows, A. J. (1998), Communicating Research, Academic Press, San Diego.

Menzel, H. (1966), "Information needs and uses in science and technology", in Cuadra, C. Z. (Ed.), Annual Review of Information Science and Technology, Wiley and Sons, New York, Vol. 1, pp. 41-69.

Schauder, D. (1994), "Electronic publishing of professional articles: attitudes of academics and implications for the scholarly communication industry", Journal of the American Society for Information Science, Vol 45 No 2, pp. 73-100.

Seyal, A. H., Abd-Rahman, M. N. and Mahbubur-Rahim, M. (2002), "Determinants of academic use of the Internet: a structural equation model", Behaviour and Information Technology, Vol. 21 No 1, pp. 71-86.

Shaw, W. (1998), "The use of the Internet by English academics", Information Research, Vol. 4 No 2, available at: http://informationr.net/ir/6-2/ws8.html (accessed 7 November 2009).

Simonton, W. C. (1960), Characteristics of the Research Literature in the Fine Arts During the Period 1948-1957, Unpublished Doctoral Thesis, University of Illinois, Chicago.

Skelton, B. (1973), "Scientists and social scientists as information users: a comparison of results of science user studies with the investigation into information requirements of the social sciences", Journal of Librarianship, Vol. 5, pp. 138-156.

Talja, S. and Maula, H. (2003), "Reasons for the use and non-use of electronic journals and databases: a domain analytic study in four scholarly disciplines", Journal of Documentation, Vol. 59, pp. 673-691.

Tenopir, C. (2003), "Use and users of electronic library resources: An overview and analysis of recent research studies", Council on Library and Information Resources, Washington, available at: 
http://www.clir.org/pubs/reports/pub120/contents.html (accessed 7 November 2009).

Torma, S. and Vakkari, P. (2004), "Discipline availability of electronic resources and the use of Finnish National Electronic Library - FinELib", Information Research, Vol. 10, No 1, available at: http://informationr.net/ir/101/paper204.html (accessed 7 November 2009).

Uddin, M. N. (2003), "Internet use by university academics: a bipartite study of information and communication needs", Online Information Review, Vol. 27, pp. 225-237.

United Nations Development Programme (2003), Arab Human Development Report 2003: Building a Knowledge Society, UNDP, New York, available at: http://www.arab-hdr.org/publications/other/ahdr/ahdr2003e.pdf (accessed 7 November 2009).

Wang, Y.-M. and Cohen, A. (2000), "Communicating and sharing in cyberspace: University faculty use of internet resources", International Journal of Educational Telecommunications, Vol. 6 No 4, pp. 303-315.

White, L. M. (1997), "The Humanities", in Gaff, J. E. (Ed.), Handbook of the Undergraduate Curriculum: A Comprehensive Guide to Purposes, Structures, Practices, and Change, Jossey-Bass, San Francisco, pp. 262-279.

Zhang, Y. (1999), "Scholarly use of Internet-based electronic resources: a survey report", Library Trends, Vol. 46 No 4, pp. 746-770. 